\title{
Ethnobotanical and Phytopharmacological attributes of Mesua ferrea: A mini review
}

\author{
Muhammad Asif $^{1 *}$, Seyedeh Fatemeh Jafari ${ }^{1}$, Zafar Iqbal ${ }^{2}$, Vageesh Revadigar ${ }^{2}$, Chern Ein Oon $^{3}$, Aman Shah Abdul \\ Majid $^{4}$, Amin Malik Shah Abdul Majid ${ }^{1}$ \\ ${ }^{1}$ EMAN Testing and Research Laboratory, Department of Pharmacology, School of Pharmaceutical Sciences, Universti Sains Malaysia, Penang 11800 , \\ Malaysia. ${ }^{2}$ Department of Pharmacology, School of Pharmaceutical Sciences, Universti Sains Malaysia, Penang 11800, Malaysia. ${ }^{3}$ Institute for Research in \\ Molecular Medicine (INFORMM), Universti Sains Malaysia, Penang, 11800, Malaysia. ${ }^{4}$ Department of Pharmacology, School of Medical Sciences, Quest \\ International University, Perak, Malaysia.
}

\section{ARTICLE INFO \\ Article history: \\ Received on: 23/07/2016 \\ Accepted on: 18/12/2016 \\ Available online: 30/04/2017 \\ Keywords: \\ Mesua ferrea, guttiferae, anticancer, antioxidant, anti- inflammatory, standardised extract.}

\begin{abstract}
Members of guttiferae family are widely distributed in the tropical areas of the world, especially Asian countries and are traditionally used by the local people for the treatment of various ailments ranging from headache to cancer. Mesua ferrea $\mathrm{L}$. is an important member of this family, which has been shown to possess multifactorial pharmacological activities. This review highlights the traditional uses, phytochemical profiling and proven pharmacological attributes of different parts of $M$. ferrea. Almost every part of the plant is reported to have beneficial medicinal properties that can help to fight against different aliments. However, further studies are still required to explore the molecular targets responsible for the observed pharmacological activities and to test the efficacy of isolated compounds or standardized extracts in properly designed experiments. In addition, long term toxicity studies are also required to establish the safety profile of isolated compounds/standardised extracts before the commencement of clinical trials.
\end{abstract}

\section{INTRODUCTION}

The guttiferae family is a rich source of secondary metabolites and is blessed with a variety of medicinal properties. It is comprised of 47 genera with more than 100 species. The well-known genera of this family are Cratoxylum, Hypericum, Garcinia, Mesua, and Vismia and are widely distributed in the tropical Asia, Africa, Brazil, New Caledonia and Polynesia (Gontijo et al., 2012; Piccinelli et al., 2005).

* Corresponding Author

Muhammad Asif, EMAN Testing and Research Laboratory, Department of Pharmacology, School of Pharmaceutical Sciences, Universti Sains Malaysia, Penang, Malaysia.Email: aminmalikshah @gmail.com
Traditionally various species of Mesua are used by the inhabitants of Asian countries for the treatment of a variety of ailments including asthma, cough, dyspepsia, fever, itchiness, nausea and renal diseases. Several pharmacological attributes of Mesua species such as antioxidant, antimicrobial, antiviral, antitumor and immunomodulatory have already been proved (Teh et al., 2012; Asif et al 2016).

In the recent years, plenty of research has been conducted to explore the phytochemical composition and pharmacological activities of crude extracts and isolated compounds obtained from different parts of Mesua ferrea, therefore, this review article was designed to highlight the recent advancement in the areas of phytochemical characterization and pharmacological profiling of this medicinally important tree. 


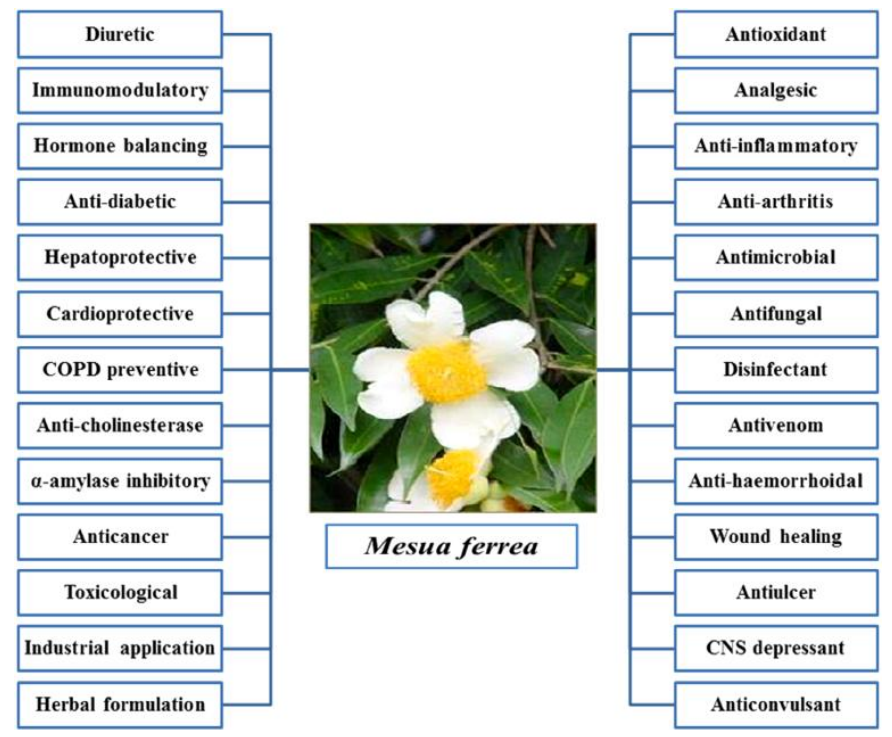

Fig. 1: Brief overview of Mesua ferra

\section{MATERIAL AND METHODS}

The information on Mesua ferrea was collected from the literature available in the books on medicinal plants and the scientific databases like PubMed, Google Scholar, Springer, and ScienceDirect. Different combination of keywords i.e., "Mesua", "Mesua ferrea", "Pharmacological”, “Anticancer", "Antioxidant', "Review", Phytopharmacological" and "Phytochemistry" were applied to retrieve information available on the topic. The references of selected articles were also screened manually for additional studies. We also searched key journals which included BMC Complementary and Alternative Medicine, Fitoterapia, Journal of Ethnopharmacology, International Journal of Immunopharmacology, Phytomedicine, Phytochemistry, Phytotherapy Research and Tetrahedron to find some relevant information about the topic.

\section{PLANT DESCRIPTION}

Mesua ferrea is an evergreen medium to large-sized ornamental tree that is distributed in most of Asian countries including Burma, Cambodia, Indochina region, Malaysia, Myanmar, Nepal (southern), Philippines, Sri Lanka, Sumatra and Thailand. Young leaves are reddish yellow in colour while mature leaves are blue grey to dark green in appearance and are approximately $7-15 \mathrm{~cm}$ long. Flowers are large in size, have four white petals containing numerous yellow coloured stamens in the centre and are fragrant. Fruits are often beaked, lightly woody in appearance containing 1-4 seeds. Bark is reddish brown in colour. Flower, fruit, seeds and leaves of this plant are edible. Flowers are eaten in Thailand by the local people for the cure of a variety of disorders. Ripe fruits have chestnut like taste when eaten. Seeds are edible when cooked but have an unpleasant taste. The leaves are edible in raw form and have a sour astringent taste (Lim, 2012).
Botanical names: Mesua ferrea L., Calophyllum nagassarium Burm. f., Mesua nagassarium (Burm. f.) Kosterm.

English name: Ceylon Ironwood, Cobra's Saffron, Indian Rose Chestnut, Mesua.

Local name: Penaga Lilin, Penage Putih, Tapis (Malaysian), Tagayasan (Japanese), Croco Di Cobra (Italian), Nagasari Gede, Nagasari (Indonesian), Nagakesar (Indian), Nagasbaum (German), Arbe De Fer (Franch), Ijzerhout (Dutch), Tie Li Mu (Chinese), Nageshwar (Bangladeshi), Narae-Kaisar (Arabic).

Taxonomical order: Kingdom - Plantae; Phylum - Tracheophyta; Class - Magnoliopsida; Order - Malpighiales; Family Calophyllaceae / Guttiferae; Genus - Mesua; Species - Mesua ferrea $\mathrm{L}$.

Parts used: Bark, flowers, fruits, leaves, root, stamens and seeds.

\section{TRADITIONAL USES}

Various parts of $M$. ferrea are used either alone or in combination with other medicinal herbs by the inhabitants of India, Pakistan, Indochina, Malaysia and Thailand for the treatment of various disorders (Ratnamhin et al., 2011). Traditionally, M. ferrea is used as an antipyretic, antimicrobial, anticancer, carminative, cardiotonic, diuretic, and expectorant (Chahar et al., 2012; Rahman et al. 2008). In Malaysia, poultice of seed oils or crushed kernels are used for wound healing while the flowers and root decoction is used by women after child birth (Lim, 2012). In Thailand, seeds are used as aroma, cardiotonic, expectorant and wound healer (Wetwitayaklung et al., 2008). In India, it is used in a variety of Ayurvedic formulations (Brahma Ramayana and Chyawanprash) as an immunity booster agent. It is also used as a herbal supplement for the treatment of a variety of diseases including bleeding piles, cough, cardiovascular disorders, dysentery, excessive thirst, headache, hiccup, itching, sweating, scabies, skin problems, small tumors and vomiting respectively (Joseph et al., 2010; Lim, 2012). Dried flowers have antiinflammatory and stomachic properties (Lim, 2012). Bark is traditionally used for the treatment of cough, dysentery, sore throat and vomiting (Keawsa-ard and Kongtaweelert, 2012). Powder of dried fruits and leaves mixed with ghee is used by the local communities of Bangladesh to get relief from burning sensation in hands and feet, joint pain and cold (Sharkar et al., 2013). M. ferrea is an important ingredient of the Indian Siddha medicine (Yelaathi Churanam) which is used internally to treat chancres, leprosy and ulcers. It is prescribed in combination with butter and sugar in Indian system of herbal medicine for the treatment of bleeding piles. Another herbal formulation (Jawarish-e-Naaremushk) is prescribed in hepatic and intestinal problems (Khare, 2004). An Ayurvedic formulation (Maharisi amrit kalash-4) containing $M$. ferrea is traditionally used to treat cancer in India and neighbouring countries (Saxena et al., 2008; Asif et al., 2016). 
Similarly, M. ferrea is also used for the treatment of inflammation and other cancer associated disorders (Rai et al., 2000). Another polyhebral formulation named Kanakasava containing $M$. ferrea is traditionally used as an anti-asthmatic agent in India (Arora and Ansari, 2014).

\section{PHYTOCHEMICAL STUDIES}

A substantial amount of efforts has been invested to identify and isolate different types of phytoconstituents from various parts of $M$. ferrea. In general, it is reported to contain coumarins, xanthones, terpenoids and sterol type of phytochemicals (Keawsa-ard et al., 2015). An extensive research is undergoing on the stem, heartwood, roots, stem bark and oleogum resin of $M$. ferrea and till date a large number of phytochemicals have been isolated and identified. From heartwood mesuaxanthone-A, mesuaxanthone-B, 1,5-dihydroxyxanthone (II), euxanthone 7-methyl ether (IV) and $\beta$-sitosterol were isolated by various research groups (Chow and Quon, 1968; Govindachari et al., 1967a). Ferrol-A, an alkylcoumarin, was later isolated by Govindachari et al. from the trunk bark of $M$. ferrea (Govindachari et al., 1967b). Eight different types of xanthones i.e., 2-Hydroxy-, 2-methoxy-, 4-hydroxy-, 1,5-dihydroxy-, 1,7-dihydroxy-, 1hydroxy-5-methoxy-, 1-hydroxy-7-methoxy-, 3-hydroxy-4methoxy- and 1,5,6-trihydroxyxanthone were isolated by Gunasekera and colleagues from the timber (Gunasekera et al., 1975). Ferrxanthone, which was chemically characterized as 1,3dimethoxy-5,6-dihydroxyxanthone was isolated from the heartwood (Walia and Mukerjee, 1984). Choudhury and colleagues analysed the essential oils contents of the bark, leaves, buds, and flowers (full bloom) of $M$. ferrea using high resolution GC and HRGC/MS techniques. The bark oil was found to be mainly composed of (E)- $\alpha$-bisabolene (31.3\%) and $\alpha$-selinene
$(12.2 \%)$, while the major oils contents of tender and mature leaves were found to be $\alpha$-copaene $(19.3 \%$ and $9.9 \%)$ and $\beta$ caryophyllene $(18.8 \%$ and $26.0 \%)$ respectively. $\alpha$-copaene $(28.7 \%$ and $20.2 \%)$ and germacrene D (19.0\% and $16.1 \%)$ were found to be the major oil components of the bud and flowers (Choudhury et al., 1998).

Another research group isolated betulinic acid, (-) epicatechin, 1,6-dihydroxyxanthone, pyranojacareubin along with two novel compounds i.e., mesuabixanthone-A and mesuabixanthone-B from the stem bark of M. ferrea (Singh et al., 1993). Later, mesuferrol-A and -B, (-) epicatechin, 1,7-dihydroxyand 5-hydroxy-1-methoxyxanthone were isolated from the stem bark by Iinuma and colleagues (Iinuma et al., 2004). Mesuaferrin$\mathrm{A}$ and -B, caloxanthone C, 1,8-dihydro-3-methoxy-6methylanthraquinone, $\beta$-sitosterol, friedelin and betulinic acid have been recently isolated from the root bark by one research group (Teh et al., 2011). Similarly, from the stems and stem bark mixture of amyrins ( $\alpha$ and $\beta$ ), $\beta$-sitosterol, calophyllin-B, dehydrocycloguanandin, euxanthone, euxanthone 7-methyl ether (IV), ferruol A, ferrxanthone, friedelin, lupeol, mesuaxanthone-A and mesuaxanthone-B, 1,5-dihydroxyxanthone (II), stigmasterol, jacareubin and 6-desoxy jacareubin have been isolated by different research groups (Gunasekera et al., 1975, Keawsa-ard et al., 2015; Lim, 2012). A new xanthone, mesuaferrin $\mathrm{C}$, along with macluraxanthone, caloxanthone $\mathrm{C}, \beta$-sitosterol, friedelin and betulinic acid was isolated from the root bark by another research group (Ee et al., 2012). Likewise, Teh and colleagues isolated seven xanthones namely, caloxanthone C, mesuaferrin-A, -B and $\mathrm{C}$, macluraxanthone, 1,5-dihydroxyxanthone and tovopyrifolin $\mathrm{C}$ from the root bark of $M$. ferrea (Teh et al., 2013). HPLC analysis of methanol and chloroform extracts of $M$. ferrea reveals the presence of a variety of natural antioxidants namely coumaric acid, ellagic acid, gallic acid, kaempferol, myricetin, rutin, quercetin,

Table 1: Highlights of phytochemical composition of selected parts of M. ferrea.

\begin{tabular}{|c|c|c|}
\hline Plant part & Compounds & References \\
\hline \multirow{3}{*}{ Heartwood } & Mesuaxanthone-A, mesuaxanthone-B & (Govindachari et al. 1967) \\
\hline & 1,5-dihydroxyxanthone (II), euxanthone 7 -methyl ether (IV), $\beta$-sitosterol & (Chow and Quon 1968) \\
\hline & Ferrxanthone (1,3-dimethoxy-5,6-dihydroxyxanthone) & (Walia and Mukerjee 1984) \\
\hline Trunk bark & Ferrol-A & (Govindachari et al. 1967) \\
\hline Timber & $\begin{array}{l}\text { 2-Hydroxy-, 2-methoxy-, 4-hydroxy-, 1,5-dihydroxy-, 1,7-dihydroxy-, 1-hydroxy-5-methoxy-, 1-hydroxy-7- } \\
\text { methoxy-, 3-hydroxy-4-methoxy- and 1,5,6-trihydroxyxanthone }\end{array}$ & (Gunasekera et al. 1975) \\
\hline Bark & (E)- $\alpha$-bisabolene and $\alpha$-selinene & (Choudhury et al. 1998) \\
\hline \multirow[b]{2}{*}{ Stem bark } & Mesuferrol-A and -B, (-) epicatechin, 1,7-dihydroxy- and 5-hydroxy-1-methoxyxanthone & (Iinuma et al. 2004) \\
\hline & Friedelin, $3 \beta$ friedelanol, lupeol, 3-oxo-betulin and spinasterol & (Islam et al. 2014) \\
\hline---- & $\begin{array}{l}\text { Calophyllin-B, dehydrocycloguanandin, euxanthone, mesuaxanthone-A, mesuaxanthone-B, jacareubin, 6- } \\
\text { desoxy jacareubin }\end{array}$ & (Gunasekera et al. 1975) \\
\hline Stems & Amyrin ( $\alpha$ and $\beta), \beta$-sitosterol, friedelin, lupeol, & (Keawsa-ard et al. 2015) \\
\hline \multirow[t]{3}{*}{ Root bark } & $\begin{array}{l}\text { Mesuaferrin-A and -B, caloxanthone } \mathrm{C}, 1,8 \text {-dihydro-3-methoxy-6-methylanthraquinone, } \beta \text {-sitosterol, friedelin } \\
\text { and betulinic acid }\end{array}$ & (Teh et al. 2011) \\
\hline & Mesuaferrin $\mathrm{C}$, macluraxanthone, caloxanthone $\mathrm{C}, \beta$-sitosterol, friedelin and betulinic & (Ee et al. 2012) \\
\hline & Caloxanthone $\mathrm{C}$, mesuaferrin-A, -B and -C, macluraxanthone, 1,5-dihydroxyxanthone and tovopyrifolin $\mathrm{C}$ & (Teh et al. 2013) \\
\hline$-\cdots$ & Coumaric acid, ellagic acid, gallic acid, kaempferol, myricetin, rutin, quercetin, and vanillic acid & (Rajesh et al. 2013). \\
\hline
\end{tabular}

---- shows parts of plant used for isolation not mentioned in the study. 
and vanillic acid (Rajesh et al., 2013). Preliminary phytochemical screening of ethanol extract of $M$. ferrea leaves showed that it contains $14.72 \mathrm{mg} / \mathrm{g}$ of dry weight extract of total phenolic contents, $11.25 \mathrm{mg} / \mathrm{g}$ of dry weight extract of total tannin contents, $30 \mathrm{mg} / \mathrm{g}$ of dry weight extract of total flavonoid contents (rutin equivalent) and $3.60 \mathrm{mg} / \mathrm{g}$ of dry weight extract of total flavonol contents (rutin equivalent) respectively (Sahu Alakh et al., 2013b). Similarly, another recent study reports the presence of friedelin, $3 \beta$ friedelanol, lupeol, 3-oxo-betulin and spinasterol in the stem bark of $M$. nagassarium (Islam et al., 2014). Two essential oils, namely (E)- $\alpha$-bisabolene and $\alpha$-selinene were also identified in the bark oil of $M$. ferrea (Alakh et al., 2014). Table 1 highlights the phytochemical composition of some selected parts of $M$. ferrea. From oleo-gum resin, isoledene, a sesquiterpene, has been identified by Asif and colleagues in their recent study (Asif et al., 2016).

\section{PHARMACOLOGICAL STUDIES}

Recent scientific studies have highlighted the medicinal importance of different parts of $M$. ferrea against a variety of human ailments.

\section{Antioxidant activity}

$70 \%$ ethanol extract of $M$. ferrea leaves have been shown to have better antioxidant activity in DPPH, superoxide and hydroxyl radical scavenging assays as compared with other solvent extracts i.e., hexane, ethyl acetate and methanol. However, the antioxidant activity of $70 \%$ ethanol extract was found to be lower when compared with standard antioxidant agent (ascorbic acid) (Prasad et al., 2012). Another study conducted by Sahu Alakh and colleagues showed modest antioxidant activity of methanol extract of flowers in DPPH free radical $\left(\mathrm{IC}_{50}=300 \mu \mathrm{g} / \mathrm{mL}\right)$, superoxide $\left(\mathrm{IC}_{50}=273.56 \mu \mathrm{g} / \mathrm{mL}\right)$, and hydrogen peroxide $\left(\mathrm{IC}_{50}=21.70\right.$ $\mu \mathrm{g} / \mathrm{mL}$ ) scavenging assays (Sahu Alakh et al., 2013a). Similarly, in another study polar extract (methanol) of $M$. ferrea roots was found to be more active as compared with less polar and non-polar extracts (Teh et al., 2013). Essential oils obtained from the leaves showed moderate antioxidant activity in the DPPH assay with an $\mathrm{IC}_{50}$ value of $31.67 \mathrm{mg} / \mathrm{mL}$ (Keawsa-ard and Kongtaweelert, 2012). Another study reported the promising antioxidant activities of water and hot water extracts of $M$. ferrea flowers in the DPPH scavenging assay and effects were shown to be even stronger than standard agent i.e., butylated hydroxytoulene (BHT) with an $\mathrm{EC}_{50}$ values of 7.49 and $6.95 \mu \mathrm{g} / \mathrm{mL}$ respectively (Makchuchit et al., 2010). Chloroform and methanol extracts of $M$. ferrea stem bark have been shown to have good antioxidant activity in the in vitro antioxidant models. Both extracts protected erythrocytes, haemoglobin and DNA against oxidative stress-induced damage. The methanol extract showed strong activity (> 90\%) as compared with chloroform extract $(>70 \%<90 \%)$. This was suggested to be due to higher total phenolic and flavonoid contents of methanol extract (Rajesh et al., 2013). In another recent study, n-hexane extract of $M$. ferrea stamens has been reported to possess good free radical scavenging activity with an $\mathrm{IC}_{50}$ value of $66.3 \mu \mathrm{g} / \mathrm{mL}$. However, one major drawback of this study was that no standard drug was used to compare the efficacy of active stamen extract (Barbade and Datar, 2015).

\section{Analgesic activity}

In an acetic acid-induced visceral pain mouse model, non-polar (n-hexane) fraction of $M$. ferrea leaf extract showed better antinociceptive activity in terms of percent reduction in writhing response as compared with polar fractions (methanol and ethyl acetate) (Hassan et al., 2006; Lim, 2012).

\section{Anti-inflammatory and anti-arthritis activities}

Anti-arthritis activities of $M$. ferrea seed extracts were evaluated in two different in vivo models i.e., Formaldehydeinduced and Complete Freund's Adjuvant (CFA) -induced arthritis in rats. In formaldehyde-induced model, significant reduction in the swelling of formaldehyde injected paw was observed in the seed extract treated rats compared to the control animals. Similarly, in CFA model, reduction in the arthritis lesions as noted by swelling volume in CFA injected paw was observed in $M$. ferrea seed extracts treated animals. An increase in body weight of $M$. ferrea seed extract treated rats was also observed, while in control CFA injected rats a decrease in body weight was observed at the end of treatment (Jalalpure et al., 2011).

In vivo anti-inflammatory activities of xanthones i.e., mesuaxanthone-A, mesuaxanthone-B, calophyllin-B, dehydrocycloguanandin, euxanthone, jacareubin and 6-desoxy jacareubin isolated from $M$. ferrea were studied using three different rat inflammation models. All the xanthones were revealed to have promising anti-inflammatory activities in carrageenan-induced paw oedema, cotton pellet granuloma and granuloma pouch inflammatory models (Gopalakrishnan et al. 1980). In addition, an ayurvedic formulation (Shirishavaleha) containing $M$. ferrea in combination with other herbs has been shown to inhibit oedema development in carrageenan-induced paw oedema model (Yadav et al., 2010). Similarly, another recent study, reports the promising anti-inflammatory activity of $80 \%$ ethanol extract of stem bark in a variety of in vitro bioassays. The finding of the study revealed that $80 \%$ ethanol extract at the concentration of 100,200 and $500 \mu \mathrm{g} / \mathrm{mL}$ has stronger antiinflammatory activity in all the in vitro bioassays as compared with standard drug i.e., Indomethacin $(100 \mu \mathrm{g} / \mathrm{mL})$ (Ranganathaiah et al., 2016).

\section{Antimicrobial and antifungal activities}

Antimicrobial activities of different parts of $M$. ferrea have been highlighted by various scientific studies. Coumarins (4alkyl and 4-phenyl 5,7-dihydroxycoumarins) isolated from the blossoms showed selective antibacterial activities towards resistant strains of gram positive bacteria (Verotta et al., 2004). Methanol extract of the leaves has been shown to possess broad spectrum antibacterial activities against Bacillus species, Escherichia coli, 
Staphylococcus aureus, Shigella, Salmonella and Lactobacillus arabinosus bacterial strains respectively (Mazumder et al., 2003). In addition to in vitro antibacterial activity, methanol extract of leaves has shown profound protective effects in the mice against Salmonella typhimurium infection (Mazumder et al., 2004). Narender Prasad and colleagues also reported that methanol extract of M. ferrea leaves at the concentration of $1200 \mu \mathrm{g} / \mathrm{mL}$ has reasonable antibacterial activity (Narender Prasad et al., 2011).

Similarly, polar extract (chloroform) of stem bark has been reported to exert strong antibacterial activity against gram positive Streptococcus aureus as well as gram negative Escherichia coli bacterial strains (Ali et al., 2004; Lim, 2012). Likewise, another research group tested the antibacterial efficacy of flower extract against five different strains of Salmonella spp and was found to be active towards all the strains at the concentration of $50 \mu \mathrm{g}$. In addition, flower extract also showed promising in vivo antibacterial activity in S. Typhimurium NCTC 74 challenged mice and caused a statistically significant reduction in viable count of bacterial strain in liver, spleen and heart blood at the dose of 2-4 mg/mouse (Mazumder et al., 2005). Methanol extract of $M$. ferrea seeds also showed fungicidal activities against different strains of fungus, including Candida albicans, Trichosporon beigelii, Mucor hiemalis and different species of Aspergillus (Lim, 2012). Likewise, a recent study reports the antibacterial activity of $M$. ferrea seed oil epoxy resin against Klebsiella pneumoniae (gram negative) and Staphylococcus aureus (gram positive) strains of bacteria (Das et al., 2014). A gel formulation containing six different herbs, including $M$. ferrea was screened for its potential to prevent skin infections associated with the resistant strains of Staphylococcus aureus, Pseudomonas aeruginosa and Corynebacterium spp. Within 2 hours of contact, $100 \%$ bactericidal efficacy was observed in herbal gel treated animal group while complete eradication of infection with no rough or dry skin remnants was observed after 20 days of treatment. Moreover, herbal gel formulation showed no toxicity in skin toxicity tests (Deshmukh et al., 2009).

M. ferrea bio-oils extracted from deoiled cakes through the process of pyrolysis has been reported to have broad range of antimicrobial activities against a variety of bacterial and fungal strains, which gives a hint about possible pharmaceutical application of bio-oils (Phukan et al., 2013).

\section{Water disinfectant properties}

$M$. ferrea seed kernel oil (NSKO) has been reported to have water disinfectant properties and can be used as natural disinfectant alternative to chlorine. The study showed that kernel oil has remarkable disinfection potential and the kinetic studies suggested that NSKO fitted first-order model with a $\mathrm{k}$ value of 0.040 (Adewale et al., 2011).

\section{Antivenom activity}

Water extract prepared from the leaves of $M$. ferrea has been shown to have considerable (40\%) anti-venom activity against Heterometrus laoticus (scorpion) venom in the in vitro chick embryo fibroblast cell lysis model (Uawonggul et al., 2006).

\section{Diuretic properties}

Polyherbal combination (Draksharishta-T and $-M$ ) and its marketed formulation comprising of stamens of $M$. ferrea has been shown to induce significant diuretic, kaliuretic and natriuretic effects in the albino rats at the dose of $2.0 \mathrm{~mL} / \mathrm{Kg}$ over a period of 5 hours compared to the control group (Tiwari and Patel, 2011).

\section{Anti-hemorrhoid activities}

A polyhedral formulation containing $M$. ferrea was evaluated for its efficacy to treat bleeding piles in a preliminary clinical study using 22 subjects. Finding of the study revealed that out of 22 subjects, 16 patients had improvement in terms of reduced bleeding with no noticeable adverse effects (Paranjpe $e t$ al., 2000). Another recent study also highlights the efficacy of standardized herbal preparations $\left(\right.$ Daflon $^{\circledR}$ and Roidosanal ${ }^{\circledR}$ ) containing $M$. ferrea in terms of improvement of ano-rectal conditions in Grade I and II patients. Both preparations reduced the bleeding and pain in the hemorrhoid patients (Aggrawal et al., 2014).

\section{Wound healing activity}

Tannins isolated from the ethanol extract of aerial parts of $M$. ferrea have been shown to have promising wound healing activity in excision and incision wound healing rat models when applied in the form of an ointment. Increased epithelialization and wound contraction were proposed to be the possible mechanisms responsible for the wound healing activity of aerial parts (Choudhary, 2012).

\section{Antiulcer activity}

Xanthones i.e., jacareubin and 6-desoxy jacareubin obtained from $M$. ferrea prevented ulceration in the rats as compared with control groups where extensive ulceration, perforations and haemorrhagic spots were observed. On the other hand, in xanthones treated rats only hyperaemia and occasional haemorrhage spots were noticed (Gopalakrishnan et al., 1980; Lim, 2012).

\section{Central nervous system (CNS) depressant and anticonvulsant activities}

CNS depressant effects of xanthones (mesuaxanthone-A, mesuaxanthone-B, calophyllin-B, dehydrocycloguanandin, euxanthone, jacareubin and 6-desoxy jacareubin) obtained from $M$. ferrea were evaluated in both mouse and rat models. Typical CNS depressant effects, i.e., ptosis, sedation, loss of muscle tone and reduced spontaneous motor activity were observed in the xanthones treated animals respectively. Similarly, potentiation of anaesthetic effects of ether and phenobarbitone-induced sleeping time was also observed in the xanthone treated animals (Gopalakrishnan et al., 1980; Lim, 2012). Likewise, another research group showed that $M$. ferrea flower extract caused a 
significant increase in the pentobarbital-induced sleeping time in mouse model (Chakma et al., 2006). Ethanol extract of M. ferrea also exhibited anticonvulsant effects in the mice when tested in maximum electroshock seizures (MES) assay. The extract was revealed to reduce the duration of hind limb tonic extensions in a concentration-dependent manner (Lim, 2012).

\section{Immunomodulatory and hormone balancing activities}

Effect of mesuol isolated from the seed oil of $M$. ferrea on the immune system was studied using both humoral and cellular immune models. In humoral immune response assay, mesuol resulted in a significant increase in the antibody titer values in the rats, which were previously antibody challenged and immunized by the introduction of sheep red blood cells (SRBCs) followed by immunosuppression by cyclophosphamide. Similarly, mesuol also elicited cellular immune responses in cyclophosphamide-induced immunosuppressant rats due to the stimulation of T-cells. An increase in the thickness of foot pad was observed in mesuol treated rats when exposed to SRBCs (used as an irritant) (Chahar et al., 2012). In addition, flower extract of $M$. ferrea has also been shown to possess estrogen and progesteronelike effects which were proposed to be helpful in the correction of hormonal imbalance during menstrual disorders (Lim, 2012).

\section{Antidiabetic activity}

Methanol extract of $M$. ferrea leaves has been shown to have promising antidiabetic activity in streptozotocin-induced diabetic rats. Extract was suggested to increase the secretion of insulin from pancreatic $\beta$-cells. In addition to the insulin secretory effect, the leaf extract also reduced the blood glucose levels and normalized the body weight in the diabetic rats compared to the untreated rats. In vitro studies using mouse insulinoma pancreatic $\beta$-cell line (MIN6 $\beta$-cells) showed a dose-dependent increase in the levels of insulin as a result of methanol extract treatment and the effects were more prominent in the hyperglycemic conditions compared to normal cell culture conditions (Balekari and Veeresham, 2015).

\section{Hepatoprotective activities}

In vivo hepatoprotective effects of methanol extract of $M$. ferrea flowers were evaluated in Staphylococcus aureus inoculated male Wistar rats. One week treatment with 50, 100 and $200 \mathrm{mg} / \mathrm{Kg}$ of methanol extract showed significant improvement in the levels of liver enzymes, namely CAT, SOD, GPx, and GR with concomitant decrease in the levels of AAT and AST enzymes. Profound effects were observed at the dose of $100 \mathrm{mg} / \mathrm{Kg}$ of methanol extract (Garg et al., 2009). In another study, hepatoprotective effects of different extracts of stamens were evaluated using in vitro carbon tetrachloride-induced oxidative stress liver slice culture model. Among different extracts, n-hexane and ethanol extracts of stamens protected cultured liver slice cells against carbon tetrachloride-induced oxidative stress.

The active extracts also showed promising antioxidant activities in different in vitro free radical scavenging models i.e.,
DPPH, $\mathrm{ABTS}^{+}, \mathrm{SOD}$ and NO respectively (Rajopadhye and Upadhye, 2012).

\section{Cardioprotective activities}

A polyherbal formulation (Ashwagandharishta) and its marketed preparation containing stamens of $M$. ferrea have been shown to protect against isoproterenol-induced myocardial infarction in the albino rat model. Treatment with herbal formulation also significantly prevented the isoproterenol-induced adverse changes in the levels of serum marker enzymes such as alanine aminotransferase, aspartate aminotransferase, creatine kinase and lactate dehydrogenase with concomitant improvement in the serum lipid profile. In addition, herbal formulation pretreated animals also showed significant increase in glutathione (GSH) and reduction in malondialdehyde (MDA) contents. It was proposed that the cardioprotective activity of herbal formulation may be due to increase in in vivo antioxidants levels such as GSH and inhibition of lipid peroxidation of cardiac membranes in the treated rats (Tiwari and Patel, 2012).

\section{Protection against experimentally-induced Chronic Obstructive Pulmonary Disease (COPD)}

A study conducted in the rats showed that herbal formulation $\left(\mathrm{Bresol}^{\circledR}\right.$ ) comprising of $M$. ferrea flowers has protective effects against cigarette smoke-induced COPD in rats. The rats treated with 250 and $500 \mathrm{mg} / \mathrm{Kg}$ for five weeks showed improvement in terms of reduction in tracheal inflammation, decrease in TNF- $\alpha$ and total protein levels in the bronchoalveolar lavage fluid and maintained the normal cellular architecture of the trachea and lungs (Rafiq et al., 2013).

\section{Anticholinesterase and $\alpha$-amylase inhibitory activities}

Teh and colleagues in their recent study highlighted that the secondary metabolites isolated from different species of Mesua including $M$. ferrea have acetylcholinesterase inhibitory activities and have potential to be used in Alzheimer's disease (Teh et al., 2016). In vitro $\alpha$-amylase inhibitory assay conducted by Chakrabarti and team revealed that $M$. ferrea extract has moderate $\alpha$-amylase inhibitory activity with an $\mathrm{IC}_{50}$ value of $146.8 \mu \mathrm{g} / \mathrm{mL}$ while standard drug, acarbose, showed strong $\alpha$-amylase inhibitory activity with an $\mathrm{IC}_{50}$ value of $14.24 \mu \mathrm{g} / \mathrm{mL}$ (Chakrabarti et al., 2014).

\section{Anticancer activities}

Considerable amount of work has been done to explore the anticancer potential of different parts of $M$. ferrea. Variety of crude extracts and pure compounds have shown promising anticancer activities in the preliminary in vitro anticancer screening assays. Volatile oils rich methanol extract of $M$. ferrea flowers showed strong cytotoxic activities against T-lymphocyte leukaemia cells with an $\mathrm{IC}_{50}$ value of $12.5 \mu \mathrm{g} / \mathrm{mL}$ (Nordin et al., 2004). Ethanol extract of $M$. ferrea flower was tested against three human cancer cell lines viz., CL-6 (cholangiocarcinoma), Hep-2 (human laryngeal cancer) and Hep G2 (human hepatocarcinoma) cell lines. The finding of the study showed that ethanol extract was 
selectively toxic towards Hep-2 cell line with an $\mathrm{IC}_{50}$ value of $19.22 \mu \mathrm{g} / \mathrm{mL}$ (Mahavorasirikul et al., 2010). Essential oils isolated from $M$. ferrea leaves have also been shown to possess cytotoxic activities against three cancer cell lines viz., KB (oral carcinoma), MCF-7 (breast adenocarcinoma) and NCI-H187 (metastatic lung carcinoma) and the order of cytotoxicity was revealed to be MCF$7>\mathrm{NCI}-\mathrm{H} 187>\mathrm{KB}$ respectively. While no toxic effects were observed against African green monkey normal kidney cells (Vero) (Keawsa-ard and Kongtaweelert, 2012). n-hexane and dichloromethane extracts of $M$. ferrea roots have been reported to possess broad spectrum cytotoxic activities against a panel of human cancer cell lines. The order of sensitivity of cancer cells towards n-hexane extract was Hep G2 (human hepatocellular liver carcinoma) > HeLa (human cervical cells) > NCI-H23 (human lung adenocarcinoma) > SNU-1 (human gastric carcinoma) > IMR-32 (human neuroblastoma) > LS-174T (human colorectal adenocarcinoma) > K-562 (human erythroleukemia cells) > SKMEL-28 (human malignant melanoma cells) > Raji (human B lymphocyte). On the other hand, order of sensitivity of cancer cells towards the dichloromethane extract was Hep G2 (human hepatocellular liver carcinoma) > K-562 (human erythroleukemia cells) > NCI-H23 (human lung adenocarcinoma) > IMR-32 (human neuroblastoma) > SNU-1 (human gastric carcinoma) > LS-174T (human colorectal adenocarcinoma) > SK-MEL-28 (human malignant melanoma cells) > Raji (human B lymphocyte) respectively (Teh et al., 2013). In another study, n-hexane and dichloromethane extract of $M$. ferrea flowers has also been reported to have cytotoxic effects against CCRF-CEM (human lymphoblast leukaemia cell line). In addition both extracts were also shown to reduce resistance against doxorubicin in resistant CEM/ADR5000 cells by modulating P-glycoprotein function (Noysang et al., 2014). Another recent study also reports the anticancer activities of $M$. ferrea stem extracts and isolated compounds against three cancer cell lines i.e., KB (oral carcinoma), MCF-7 (breast adenocarcinoma) and NCI-H187 (metastatic lung carcinoma). Among different extracts, n-hexane was found to be inactive in terms of induction of cytotoxicity against all the three cancer cell lines, while dichloromethane and methanol extract was found to be more active against KB than rest of two cell lines. Interestingly, isolated compounds, i.e., $\beta$-sitosterol, friedelin and mixture of $\alpha$ - and $\beta$-amyrin were either found to be less active or even inactive in terms of cytotoxic effects as compared with active crude extracts. It was proposed in the study that multi-components are responsible for the anticancer properties of $M$. ferrea stamen extracts (Keawsa-ard et al., 2015). Another recent study conducted by Asif et al shows that oleo-gum resin extract has broad spectrum anticancer activities towards human colon carcinoma cell lines.

Table 2: Highlights of anticancer activities of $M$. ferrea.

\begin{tabular}{|c|c|c|c|c|}
\hline $\begin{array}{l}\text { Part } \\
\text { used }\end{array}$ & Model/Cell line & $\begin{array}{c}\text { Extract/ } \\
\text { Compound }\end{array}$ & Findings & References \\
\hline Flowers & $\begin{array}{l}\text { T-lymphocyte } \\
\text { leukaemia cells }\end{array}$ & Methanol & Inhibited the growth of leukaemia cells with an IC50 value of $12.5 \mu \mathrm{g} / \mathrm{mL}$. & $\begin{array}{l}\text { (Nordin et al. } \\
\text { 2004) }\end{array}$ \\
\hline Flowers & $\begin{array}{l}\text { CL-6, HepG2, } \\
\text { Hep-2 }\end{array}$ & Ethanol & $\begin{array}{l}\text { Ethanol extract showed selective cytotoxicity towards Hep-2 cells with an } \mathrm{IC}_{50} \\
\text { value of } 19.22 \mu \mathrm{g} / \mathrm{mL} \text { compared with other two cell lines where } \mathrm{IC}_{50} \text { was found to } \\
\text { be above } 40 \mu \mathrm{g} / \mathrm{mL}\end{array}$ & $\begin{array}{l}\text { (Mahavorasirikul } \\
\text { et al. 2010) }\end{array}$ \\
\hline Leaves & $\begin{array}{l}\text { KB, MCF-7, } \\
\text { NCI-H187, Vero }\end{array}$ & Essential oils & $\begin{array}{l}\text { Essential oils exerted strong cytotoxic effects towards all the cancer cell line. } \\
\text { Strongest cytotoxic effects were observed in MCF-7 with an } \mathrm{IC}_{50} \text { value of } 16.19 \\
\mu \mathrm{g} / \mathrm{mL} \text {. No cytotoxic effects were observed in normal Vero cells. }\end{array}$ & $\begin{array}{l}\text { (Keawsaard and } \\
\text { Kongtaweelert } \\
\text { 2012) }\end{array}$ \\
\hline \multirow[t]{2}{*}{ Roots } & \multirow{2}{*}{$\begin{array}{l}\text { HeLa, Hep G2, } \\
\text { IMR-32, K562, } \\
\text { LS-174T, NCI- } \\
\text { H23, SNU-1, } \\
\text { SK-MEL-28, } \\
\text { Raji }\end{array}$} & n-hexane & $\begin{array}{l}\text { The order of cytotoxic susceptibility of cell lines was Hep-G2(11.45) > Hela } \\
(13.75)>\text { NCI-H23 }(16.67)>\text { SNU-1 }(17.50)>\text { IMR-32 }(20.30)>\text { LS-174T }(21.88) \\
>\text { K562 }(21.88)>\text { SK-MEL-28 }(43.75)>\text { Raji (inactive) }\end{array}$ & \multirow[t]{2}{*}{ (Teh et al. 2013) } \\
\hline & & Dichloromethane & $\begin{array}{l}\text { The order of cytotoxic susceptibility of cell lines was Hep-G2(8.85) > K562 } \\
(11.45)>\text { NCI-H23 }(13.75)>\text { IMR-32 }(15.64)>\text { SNU-1 }(22.91)>\text { LS-174T }(41.67) \\
>\text { SK-MEL-28 }(43.75)>\text { Raji (inactive) }>\text { HeLa (inactive) }\end{array}$ & \\
\hline \multirow[t]{2}{*}{ Flowers } & \multirow[t]{2}{*}{$\begin{array}{l}\text { CCRF-CEM, } \\
\text { CEM/ADR5000, } \\
\text { PBCECs }\end{array}$} & n-hexane & $\begin{array}{l}\text { n-hexane extract exhibited } 85 \% \text { growth inhibitory effects against CCRF-CEM } \\
\text { (leukemic cells) at the concentration of } 10 \mu \mathrm{g} / \mathrm{mL} \text {, while dichloromethane extract } \\
\text { inhibited } 98 \% \text { growth of CCRF-CEM cells at the concentration of } 10 \mu \mathrm{g} / \mathrm{mL} \text {. Both } \\
\text { extracts also showed activity against doxorubicin resistant CEM/ADR5000 cells }\end{array}$ & \multirow[t]{2}{*}{$\begin{array}{l}\text { (Noysang et al. } \\
\text { 2014) }\end{array}$} \\
\hline & & Dichloromethane & & \\
\hline \multirow[t]{6}{*}{ Stems } & \multirow{6}{*}{$\begin{array}{l}\text { KB, MCF-7, } \\
\text { NCI-H187, Vero }\end{array}$} & n-hexane & n-hexane showed no cytotoxic effects against any of the cell lines tested & \multirow{6}{*}{$\begin{array}{l}\text { (Keawsa-ard, } \\
\text { Liawruangrath and } \\
\text { Kongtaweelert } \\
\text { 2015) }\end{array}$} \\
\hline & & Dichloromethane & $\begin{array}{l}\text { The order of cytotoxic susceptibility of cell lines was KB (18.01) > NCI-H1 } 87 \\
(18.42)>\text { MCF-7 }(28.83)>\text { Vero (nontoxic) }\end{array}$ & \\
\hline & & Friedelin & Inactive against all the cell lines tested & \\
\hline & & Amyrin $(\alpha$ and $\beta)$ & $\begin{array}{l}\text { Amyrins mixture was only active against MCF-7 with an } \mathrm{IC}_{50} \text { value of } 28.45 \\
\mu \mathrm{g} / \mathrm{mL}\end{array}$ & \\
\hline & & Lupeol & $\begin{array}{l}\text { The order of cytotoxic susceptibility of cell lines was NCI-H187 (21.56) > KB } \\
(30.12)>\mathrm{MCF}-7(34.25)>\text { Vero (nontoxic) }\end{array}$ & \\
\hline & & $\beta$-sitosterol & Inactive against all the cell lines tested & \\
\hline \multirow[t]{2}{*}{ Flowers } & \multirow{2}{*}{$\begin{array}{l}\text { Ehrlich ascites } \\
\text { carcinoma mice } \\
\text { model }\end{array}$} & Chloroform & $\begin{array}{l}\text { Chloroform extract significantly }(* * \mathrm{p}<0.001) \text { reduced the tumor cells }(54.8 \% \\
\text { tumor growth inhibition) in treated mice }\end{array}$ & \multirow[t]{2}{*}{ (Rana et al. 2004) } \\
\hline & & Ethyl acetate & Percent inhibition of tumor growth in treated rats was $41.7 \%$ & \\
\hline $\begin{array}{l}\text { Oleo- } \\
\text { gum } \\
\text { resin }\end{array}$ & $\begin{array}{l}\text { HCT } 116, \text { HT29, } \\
\text { LIM1215 }\end{array}$ & n-hexnae & $\begin{array}{l}\text { Isoledene rich sub-fraction induced apoptosis in HCT } 116 \text { cells by modulating the } \\
\text { activity of multiple proteins }\end{array}$ & (Asif et al., 2016) \\
\hline
\end{tabular}

Values shown in brackets are expressed in $\mu \mathrm{g} / \mathrm{mL}$ 
The oleo-gum resin extract was shown to induce apoptosis in HCT 116 cells through ROS-mediated apoptotic pathways. Interestingly, oleo-gum resin extract did not induce toxicity in the normal colon cells (CCD-18co) (Asif et al., 2016) Similarly, Asif $e t a l$. in their recent study showed that terpenes rich stem bark extract has broad spectrum anticancer activities. The order of sensitivity (high to low) of cancer cell lines towards F-3 was HCT $116>$ MNK-74 > PC-3 > T-47D > MIA PaCa-2 $>$ HT $29>$ PANC-1 > MCF-7 > Capan-1 > EA.hy926 > 3T3-L1 > CCD- 18co respectively (Asif et al., 2017). In addition to variety of in vitro anticancer studies, there is also one study that reports the in vivo efficacy of chloroform and ethyl acetate extract of $M$. ferrea flowers against Ehrlich ascites carcinoma in Swiss albino mice. Percent inhibition of carcinoma in chloroform and ethyl acetate treated animals was 54.8 and $41.7 \%$ respectively (Rana $e t$ al., 2004). Table 2 highlights the anticancer activities of M. ferrea against different cancer cell lines.

\section{Toxicological studies}

Acute toxicity studies on different extracts of $M$. ferrea were conducted using albino mouse and rat models. In rat model, $5 \mathrm{~g} / \mathrm{Kg}$ doses of three different seed extracts i.e., petroleum ether, ethyl acetate and alcoholic did not provoke any signs of toxicity during the first 24 hours and no mortality in any of the test groups was observed (Jalalpure et al., 2011). Similarly, acute toxicity studies of methanol extract of $M$. ferrea flowers were performed in Swiss albino mice using three different doses i.e., 50, 500 and $2000 \mathrm{mg} / \mathrm{Kg}$. In all the treated groups, none of the mice showed any visible signs of toxicity with zero mortality rates. Moreover, there was no differences in haematological and biochemical profiles of $M$. ferrea flowers feed and control mice, respectively (Udayabhanu et al., 2014). In another recent study, n-hexane extract of M. ferrea stamens has been reported to be safe in the acute toxicity mouse model, however, the doses used and safety level was not mentioned in the study (Barbade and Datar, 2015).

\section{INDUSTRIAL APPLICATIONS}

Apart from pharmacological attributes, numerous studies have highlighted the industrial applications of $M$. ferrea seed oils as an alternative biofuel in the diesel and compression ignition engines, in paint industry, as a multi-purpose industrial coating preparation and as biomaterials (nanocomposites etc.). Stamens are used as a fragrant stuffing for cushions and pillows. Wood is considered suitable for all types of heavy construction including railway sleepers, transmission posts, heavy-duty furniture, posts and tool handles (Lim, 2012).

\section{PROPOSED PHARMACEUTICAL APPLICATIONS}

Based on scientific studies reported above, we hereby propose that $M$. ferrea has potential to be developed as a herbal pharmaceutical product in the form of topical antibacterial $\mathrm{gel} / \mathrm{cream}$, as a standardised extract for internal bleeding disorders i.e., ulcers and hemorrhoids and as a chemopreventive and chemotherapeutic agent respectively. However, further studies are still needed in this aspect.

\section{CONCLUSION}

Recent scientific studies have highlighted that $M$. ferrea is a rich source of secondary metabolites which are having multiple health promoting benefits including antioxidant, antiinflammatory, antimicrobial, anticancer and others. Several studies have recurrently highlighted the antioxidant, antimicrobial and anticancer effects of whole extracts, active fractions and pure compounds isolated from different parts of $M$. ferrea. However, there are some problems which need to be addressed, (i) conclusion of majority of studies are based on preliminary in vitro screening assays. Still further research is needed to confirm these activities by employing proper experimental tools. (ii) In majority of the studies no standard marketed drug was used as positive control and where positive control is used the efficacy of the active extract/ compound was not compared. The efficacy of active extract/ compound must be compared with standard drug as well. (iii) None of the study has reported the pharmacokinetic profile of active extract and isolated compounds. Further research is needed in this regard to estimate the feasibility of active samples for commercial drug formulation. (iv) Stamens are most commonly used in the polyherbal formulations, however, efficacy of other parts such as seeds, flowers, stems, bark and oleo-gum resin are also needed to be evaluated for the effective pharmaceutical product development. (v) Only few studies have reported the toxicity profile of selected parts, however, further studies are highly recommended in this regards before commencement of clinical studies. (vi) Standardization of active extracts is highly recommended in order to develop product of uniform composition and biological activity. (vii) Majority of studies did not identify molecular targets responsible for the biological activity; further studies to identify the molecular targets responsible for these medicinal properties especially anticancer, can help in the development of cost-effective and natural remedies against this chronic disorder.

\section{ACKNOWLEDGEMENT}

Financial support and sponsorship: Authors would like to acknowledge Universiti Sains Malaysia (USM) for supporting this project through USM research grant (304/PFARMASI/650735/K123) and Institute of Postgraduate Studies Fellowship (P-FD0009/12 (R).

Conflict of Interests: There are no conflicts of interest.

\section{REFERENCES}

Adewale AI, Mirghani MES, Muyibi SA, Daoud JI, Abimbola MM. Disinfection studies of Nahar (Mesua ferrea) seed kernel oil using pour plate method. Afr J Biotechnol, 2011; 10:18749-54.

Aggrawal K, Satija N, Dasgupta G, Dasgupta P, Nain P, Sahu AR. Efficacy of a standardized herbal preparation (Roidosanal®) in the 
treatment of hemorrhoids: A randomized, controlled, open-label multicentre study. J Ayurveda Integr Med, 2014; 5:117-24.

Alakh NS, Hemalatha S, Sairam K. Phyto-Pharmacological Review of Mesua ferrea Linn. Int J Phytopharmacol, 2014; 5:6-14.

Ali MA, Sayeed MA, Bhuiyan MSA, Sohel FI, Yeasmin MS. Antibacterial screening of Cassia fistula and Mesua ferrea. J Med Sci, 2004; 4:24-29.

Arora P, Ansari SH. Quality standard parameters of an antiasthmatic ayurvedic formulation "Kanakasava". Int J Pharmacognosy and Phytochem Res, 2014; 6:983-87.

Asif M, Shafaei A, Jafari SF, Mohamed SK, Ezzat MO, Abdul Majid AS, Oon CE, Petersen SH, Kono K, Abdul Majid AMS. Isoledene from Mesua ferrea oleo-gum resin induces apoptosis in HCT 116 cells through ROS-mediated modulation of multiple proteins in the apoptotic pathways: A mechanistic study. Tox Lett, 2016; 257:8496

Asif M, Al-Mansoub MA, Khan MDSS, Yehya AHS, Ezzat MO, Oon CE, Atif M, Abdul Majid AS, Abdul Majid AMS. Molecular mechanisms responsible for programmed cell death inducing attributes of terpenes from Mesua ferrea stem bark towards human colorectal carcinoma HCT 116 cells. J App Biomed, 2017, 15:71-80.

Balekari U, Veeresham C. Insulinotropic Activity of Methanolic Extract of Mesua ferrea Linn. J Basic Appl Sci, 2015; 11:410-17.

Barbade KD, Datar AG. Extraction, bioactivities, phytochemical investigation and in-vivo toxicity studies of Mesua Ferrea L. Stamens. Int J Pharm Pharm Sci, 2015; 7:93-97.

Chahar M, Kumar DS, Lokesh T, Manohara K. In-vivo antioxidant and immunomodulatory activity of mesuol isolated from Mesua ferrea L. seed oil. Int Immunopharmacol, 2012; 13:386-91.

Chakma TK, Khan MTH, Rahman T, Choudhuri MSK, Rajia S, Alamgir M. Screening of Bangladeshi medicinal plants for their effects on pentobarbital-induced sleeping time in mice. Ars Pharmaceutica, 2006; 47:211-17

Chakrabarti R, Singh B, Prakrith VN, Vanchhawng L, Thirumurugan K. Screening of nine herbal plants for in vitro $\alpha$-amylase inhibition. Asian J Pharm Clin Res, 2014; 7:84-9.

Choudhary GP. Wound healing activity of the ethanolic extract of Mesua ferrea Linn. Int J Adv Pharm Biol Chem, 2012; 1: 369. 71.

Choudhury S, Ahmed R, Barthel A, Leclercq PA. Volatile Oils of Mesua ferrea (L.) from Assam, India. J Essent Oil Res, 1998; 10: 497. 501.

Chow YL, Quon HH. Chemical constituents of the heartwood of Mesua ferrea. Phytochemistry, 1968; 7: 1871-74.

Das G, Kalita RD, Gogoi P, Buragohain AK, Karak N. Antibacterial activities of copper nanoparticle-decorated organically modified montmorillonite/epoxy nanocomposites. Appl Clay Sci, 2014; 90:18-26.

Deshmukh P, Gupta P, Shankar R. In vitro and in vivo efficacy of a herbal formulation against skin infections. J Pure Appl Microbio, 2009; 3:199-204.

Ee GCL, Teh SS, Rahmani M, Taufiq-Yap YH, Go R, Mah SH. A new furanoxanthone from the root bark of Mesua ferrea. Lett Org Chem, 2012; 9:457-59.

Garg S, Sharma K, Ranjan R, Attri P, Mishra P. In vivo Antioxidant activity and hepatoprotective effects of methanolic extract of Mesua ferrea linn. Int J PharmTech Res, 2009; 1:1692-96.

Gontijo VS, de Souza TC, Rosa IA, Soares MG, da Silva MA, Vilegas W, Viegas Júnior C, dos Santos MH. Isolation and evaluation of the antioxidant activity of phenolic constituents of the Garcinia brasiliensis epicarp. Food Chem, 2012; 132:1230-35.

Gopalakrishnan C, Shankaranarayanan D, Nazimudeen SK, Viswanathan S, Kameswaran L. Anti-inflammatory and C.N.S. depressant activities of xanthones from Calophyllum inophyllum and Mesua ferrea. Indian J Pharmacol, 1980; 12:181-91.

Govindachari TR, Pai BR, Subramaniam PS, Ramdas Rao U, Muthukumaraswamy N. Constituents of Mesua ferrea L.-II: Ferruol A, a new 4-alkylcoumarin. Tetrahedron, 1976a; 23: 4161-65.
Govindachari TR, Pai BR, Subramaniam PS, Rao UR, Muthukumaraswamy N. Constituents of Mesua ferrea L.-I: Mesuaxanthone A and mesuaxanthone B. Tetrahedron, 1967b; 23: 243-48.

Gunasekera SP, Ramachandran S, Selliah S, Sultanbawa MUS. Chemical investigation of ceylonese plants. Part XVII. Isolation and structures of the xanthones in the extractives of Mesua ferrea L. (form $M$. salicina Pl. and Tr.) (Guttiferae). J Chem Soc Perkin Trans 1, 1975; $2447-$ 50 .

Hassan MT, Ali MS, Alimuzzaman M, Raihan SZ. Analgesic activity of Mesua ferrea Linn. Dhaka Univ J Pharm Sci, 2006; 5:73-5.

Iinuma $\mathrm{M}$, Tosa $\mathrm{H}$, Tanaka $\mathrm{T}$, Riswan $\mathrm{S}$. Two new dimeric xanthones in Mesua ferrea. Heterocycles, 2004; 43: 1996-99.

Islam R, Ahmed I, Sikder AA, Haque MR, Al-Mansur A, Ahmed M, Rasheed M, Rashid MA. Chemical Investigation of Mesua nagassarium (Burm. f.) Kosterm. J. Basic Appl. Sci, 2014; 10: 124-28.

Jalalpure SS, Mandavkar YD, Khalure PR, Shinde GS, Shelar PA, Shah AS. Antiarthritic activity of various extracts of Mesua ferrea Linn. seed. J Ethnopharmacol, 2001; 138: 700-04.

Joseph C, Ilanchezhian R, Biswajyoti P, Harish C. Pharmacognostical study of nagakeshara (Mesua ferrea. Linn) - an ingredient in Vyaghrihareetaki Avaleha. Int J Res Ayurveda Pharm, 2010; 1:264-72.

Keawsa-ard S, Kongtaweelert S. Antioxidant, Antibacterial, Anticancer Activities and Chemical Constituents of the Essential Oil from Mesua ferrea Leaves. Chiang Mai J Sci, 2012; 39:455-63.

Keawsa-ard S, Liawruangrath B, Kongtaweelert S. Bioactive Compounds from Mesua ferrea Stems. Chiang Mai J Sci, 2015;42:185-95.

Khare CP. 2004. Indian herbal remedies : Rational Western Therapy, Ayurvedic and other Tradiotional Usage, Botany. Berlin: Springer.

Lim TK. 2012. Edible medicinal and non-medicinal plants. New York: Springer.

Mahavorasirikul W, Viyanant V, Chaijaroenkul W, Itharat A, Na-Bangchang K. Cytotoxic activity of Thai medicinal plants against human cholangiocarcinoma, laryngeal and hepatocarcinoma cells in vitro. BMC Complement Altern Med, 2010; 28:10-55.

Makchuchit S, Itharat A, Tewtrakul S. Antioxidant and nitric oxide inhibition activities of Thai medicinal plants. J Med Asso Thai, 2010; 93(Suppl 7):S227-35.

Mazumder R, Dastidar SG, Basu SP, Mazumder A, Kumar S. Emergence of Mesua ferrea Linn. leaf extract as a potent bactericide. Ancient Sci Life, 2003; 22:160-65.

Mazumder R, Dastidar SG, Basu SP, Mazumder A, Singh SK. Antibacterial potentiality of Mesua ferrea Linn. flowers. ,Phytother Res $-18: 824 ; 200426$

Mazumder R, Dastidar SG, Basu SP, Mazumder A. Effect of Mesua ferrea Linn. flower extract on Salmonella. Indian J Exp Bio, 2005; 43:566-68.

Narender Prasad D, Ganga Rao B, Prayaga Murthy P, Sambasiva Rao E, Mallikarjuna Rao T, Praneeth DVS. Evaluation of phytochemical constituents and in-vitro antibacterial activity of Mesua ferrea leaves. Int J Pharm Technol, 2011; 3:3624-30.

Nordin A, Ahmad FBH, Taufiq-Yap YH, Ali AM. Volatile Components of Methanol Extract from the Flower of Malaysian Musea Ferrea Linn. Orient J Chem, 2004; 20:69-72.

Noysang C, Mahringer A, Zeino M, Saeed M, Luanratana O, Fricker G, Bauer R, Efferth T. Cytotoxicity and inhibition of Pglycoprotein by selected medicinal plants from Thailand. J Ethnopharmacol, 2014; 155:633-41.

Paranjpe P, Patki P, Joshi N. Efficacy of an indigenous formulation in patients with bleeding piles: a preliminary clinical study. Fitoterapia, 2000; 71:41-5.

Phukan MM, Chutia RS, Kumar R, Kalita D, Konwar BK, Kataki R. Assessment of antimicrobial activity of bio-oil from Pongamia Glabra, Mesua ferrea and Parachlorella spp deoiled cake. Int J Pharm Bio Sci, 2013; 4:P910-18.

Piccinelli AL, Cuesta-Rubio O, Chica MB, Mahmood N, Pagano B, Pavone M, Barone V, Rastrelli L. Structural revision of 
clusianone and 7-epi-clusianone and anti-HIV activity of polyisoprenylated benzophenones. Tetrahedron, 2005; 61:8206-11.

Prasad DN, Rao BG, Rao ES, Rao TM, Praneeth DVS. Quantification of phytochemical constituents and in-vitro antioxidant activity of Mesua ferrea leaves. Asian Pac J Trop Biomed, 2012; 2:S539S42.

Rafiq M, Viswanatha GL, Suryakanth DA, Azeemuddin M, Jagadeesh M, Dhanush K, Patki PS. Poly-ingredient formulation Bresol® ameliorates experimental chronic obstructive pulmonary disease (COPD) in rats. Sci Pharm, 2013; 81:833-42.

Rahman SMM, Shabnom S, Quader MA, Hossain MA. Phytochemical study on the ethylacetate extract of the leaves of Mesua ferrea Linn. Indo J Chem, 2008; 8:242-44.

Rai LK, Pankaj P, Sharma E. Conservation threats to some important medicinal plants of the Sikkim Himalaya. Biol Conserv, 2000; 93:27-33.

Rajesh KP, Manjunatha H, Krishna V, Kumara Swamy BE. Potential in vitro antioxidant and protective effects of Mesua ferrea Linn. bark extracts on induced oxidative damage. Ind Crops Prod,2013;47:18698.

Rajopadhye AA, Upadhye AS. Hepatoprotective Effect of Stamen Extracts of Mesua ferrea L. against Oxidative Stress induced by CCl4 in Liver Slice Culture Model. Nat Prod Sci, 2012; 18:76-82.

Rana AYKMM, Khanam JA, Asad-Ud-Daula M. Antineoplastic Screening of Some Medicinal Plants Against Ehrlich Ascites Carcinoma in Mice. Int J Med Sci, 2004; 4:142-45.

Ranganathaiah $\mathrm{P}$, Hanumanthappa $\mathrm{M}$, Venkatarangaiah $\mathrm{K}$. Evaluation of in vitro anti-inflammatory activity of stem bark extracts of Mesua ferrea Linn. Int J Pharm Pharm Sci, 2016; 8:173-77.

Ratnamhin A, Elliott S, Wangpakapattanawong P. Vegetative Propagation of Rare Tree Species for Forest Restoration. Chiang Mai J Sci, 2011; 38:306-10.

Sahu Alakh N, Hemalatha S, Sairam K. 2013a. HPTLC fingerprinting and in vitro antioxidant studies of Argyreia speciosa sweet leaves and Mesua ferrea linn. flowers. Int J Res Ayurveda Pharm, 2013a; 4:499-502.

Sahu Alakh N, Hemalatha S, Sairam K. Quantitative phytochemical and heavy metal estimation of Mesua ferrea flowers and Argyreia speciosa leaves. Int J Pharm Sci Rev Res, 2013b; 22:276-78.

Saxena A, Dixit S, Aggarwal S, Seenu V, Prashad R, Bhushan SM, Tranikanti V, Misra MC, Srivastava A. An Ayurvedic Herbal Compound to reduce Toxicity to Cancer chemotherapy: A Randomized Controlled Trial. Indian J Med Paediatr Oncol, 2008; 29:11-18.

Sharkar P, Rahman MM, Haque Masum GZ, Nayeem MA, Hossen MM, Azad AK. 2013. Ethnomedicinal importance of the plants in villages in kushtia sador and mirpur upozila, bangladesh. J Herbs Spices Med Plants, 2013; 19:401-17.

Singh S, Gray AI, Waterman PG. Mesuabixanthone-A and Mesuabixanthone-B: Novel Bis-Xanthones from the Stem Bark of Mesua ferrea (Guttiferae). Nat Prod Lett, 1993; 3:53-8.

Teh S, Ee G, Mah S, Yong Y, Lim Y, Rahmani M, Ahmad Z. In vitro cytotoxic, antioxidant, and antimicrobial activities of Mesua beccariana (Baill.) Kosterm., Mesua ferrea Linn., and Mesua congestiflora extracts. Biomed Res Int, 2013; 2013:5170-72.

Teh S, Ee G, Rahmani M, Taufiq-Yap Y, Go R, Mah S. Pyranoxanthones from Mesua ferrea. Molecules, 2011; 16:5647-54.
Teh SS, Ee GCL, Mah SH, Ahmad Z. Structure-activity relationship study of secondary metabolites from Mesua beccariana, Mesua ferrea and Mesua congestiflora for anti-cholinesterase activity. Med Chem Res, 2016; 25(5):1-5.

Teh SS, Ee GCL, Mah SH, Lim YM, Rahmani M. Mesua beccariana (Clusiaceae), A Source of Potential Anti-cancer Lead Compounds in Drug Discovery. Molecules, 2012; 17:10791-800.

Teh SS, Ee GCL, Mah SH. Chemical Constituents and New Xanthone Derivatives from Mesua ferrea and Mesua congestiflora. Asian J Chem, 2013; 25:8780-84.

Tiwari P, Patel RK. Evaluation of diuretic potential of draksharishta prepared by traditional and modern methods in experimental rats. Pharmacologyonline, 2011; 3:566-72.

Tiwari P, Patel RK. Cardioprotective activity of ashwagandharishta on isoproterenol induced myocardial infarction. Pharmacologyonline, 2012; 1:17-24.

Uawonggul N, Chaveerach A, Thammasirirak S, Arkaravichien T, Chuachan C, Daduang S. 2006. Screening of plants acting against Heterometrus laoticus scorpion venom activity on fibroblast cell lysis. J Ethnopharmacol, 2006; 103:201-7.

Udayabhanu J, Kaminidevi S, Thangavelu T. A study on acute toxicity of methanolic extract of Mesua ferrea L. in Swiss albino mice. Asian J Pharm Clin Res, 2014; 7:66-8.

Verotta L, Lovaglio E, Vidari G, Finzi PV, Neri MG, Raimondi A, Parapini S, Taramelli D, Riva A, Bombardelli E. 4-Alkyl- and 4phenylcoumarins from Mesua ferrea as promising multidrug resistant antibacterials. Phytochemistry, 2004; 65:2867-79.

Walia S, Mukerjee SK. Ferrxanthone, a 1,3,5,6-tetraoxygenated xanthone from Mesua ferrea. Phytochemistry, 1984; 23:1816-17.

Wetwitayaklung P, Phaechamud T, Limmatvapirat C, Keokitichai S. The Study of Antioxidant Activities of Edible Flower Extracts; 2008: International Society for Horticultural Science (ISHS). Leuven, Belgium.

Yadav SS, Galib, Ravishankar B, Prajapati PK, Ashok BK, Varun B. Anti-inflammatory activity of Shirishavaleha: An Ayurvedic compound formulation. Int J Ayurveda Res, 2010; 1:205-7.

How to cite this article:

Asif M, Jafari SF, Iqbal Z, Revadigar V, Oon CE, Majid ASA, Majid AMSA. Ethnobotanical and Phytopharmacological attributes of Mesua ferrea: A mini review. J App Pharm Sci, 2017; 7 (04): 242-251. 